\title{
Regional Financial Integration in East Asia against the Backdrop of Recent European Experiences
}

\author{
Ulrich Volz \\ SOAS, University of London \\ and \\ German Development Institute
}

\section{January 2015}

This article discusses recent trends in regional financial integration in East Asia and current efforts of the Association of Southeast Asian Nations (ASEAN) member countries to foster regional financial integration against the backdrop of three decades of experience with financial integration in Europe. It reviews the two major crisis episodes of the recent European financial history to illustrate the risks associated with comprehensive capital account liberalisation and financial integration without commensurate supervisory structures. The article highlights the importance of targeted macroprudential policies and the development of an adequate region-wide regulatory and supervisory framework to reduce the risks associated with regional - and hence international financial integration. 
Keywords: Regional financial integration; East Asia; financial stability.

JEL Classification: E44, F36

Address for correspondence: Department of Economics, SOAS, University of London. Russell Square, London WC1H 0XG, UK. Tel: +44 207898 4721. Email: uv1@soas.ac.uk 


\section{Introduction}

Cross-border bank lending has increased substantially in the Asia-Pacific region since the Global Financial Crisis of 2007-09 (Remolona and Shim, 2015). The region has also seen an increase in intra-regional portfolio investments. The growing importance of intra-regional cross-border lending and investment is a break from the past in which (long term) financial investments primarily went to the US and Europe, only to be partly channelled back to the East Asian region in the form of short-term lending and investment. This round-tripping of capital and the reliance on financial intermediation in the financial centres of the West has for long increased the vulnerability to the developing and emerging economies of East Asia. It has also held back the development of banking and capital markets in the East Asian region and perpetuated the dependency on the US dollar as the dominant trade and investment currency for the region and indeed the world economy.

A lesser reliance on Western financial markets should be in principle welcomed not only in East Asia. Deeper and more robust and stable financial systems in the East Asian region that are less exposed to shocks emanating in the US or Europe will also increase the resilience of the global financial system. A further development of deep and liquid local currency sovereign and corporate bond markets that provide means for much needed long-term investment in infrastructure and elsewhere can provide an important bedrock for sustainable development of the region. Likewise, the development of a solid region-wide banking system that offers important services in transaction banking, especially in trade finance, and in wholesale banking, especially in infrastructure finance, can contribute to sustainable regional economic development.

Yet, regional financial integration also carries risks. Liberalising the capital account is a risky affair in general, and unlike in trade where rules of origin allow for discrimination, in finance it is difficult if not impossible to distinguish between 'regional' and 'global' capital flows. In East Asia, the Asian Financial Crisis of 1997-98 has illustrated both the risks of badly managed capital account liberalisation and the risk of contagion of financial crisis along regional lines (Glick and Rose, 1999). Recent European experiences with financial integration and crises underscore these risks. Against the background of current efforts to boost regional financial integration among the ten member countries of the Association of Southeast Asian Nations (ASEAN), this article reviews two crisis episodes of recent European financial history to illustrate the risks associated with comprehensive capital account liberalisation and efforts to promote regional financial integration across the European Union. Although there are substantial differences between the two regions, the European experiences suggest that ASEAN countries need to be very cautious in implementing their ambitious financial integration agenda. The article highlights the importance of targeted macroprudential policies and the development of an adequate regionwide regulatory and supervisory framework to minimise risks associated with regional financial integration.

The next section re-examines the policy efforts to reduce barriers to financial integration in Europe since the late 1970s and discusses the roles that financial integration has played in the crisis of the European Monetary System (EMS) in 1992 and in the euro crisis since 2010, 
respectively. Section 3 will subsequently consider recent trends in regional financial integration in East Asia and policy efforts to promote further regional financial integration among ASEAN and the associated risks. Section 4 concludes.

\section{Experiences with financial integration in Europe}

\subsection{Financial integration and liberalisation of cross-border flows in Europe}

European countries gradually dismantled restrictions to cross-border financial flows from the second half of the 1970s onwards. Fostering financial market integration was commonly seen as way of supporting further trade integration. Liberalising barriers to capital flows and integrating regional financial markets was expected to improve the allocation of capital and unleash the growth potential of the member states. European financial integration was in principal fostered through market deregulation, especially an abolition of capital account restrictions, and an agreement on common legislative standards. The European Community's First and Second Banking Directives were the centrepieces for the harmonisation of regulation and financial integration. The First Banking Directive on the Co-ordination of Laws, Regulations and Administrative Provisions Relating to the Taking Up and Pursuit of Credit Institutions was adopted in 1977. It was the first step towards the harmonisation of banking regulation across (then Western) Europe. It applied the principle of nondiscrimination against businesses from other member states to the banking sector. The First Banking Directive also established the principle of home country control, which maintains that responsibility for the supervision of a bank rests with the supervisory authority of the home country of the parent institution.

The Second Banking Directive of 1989 established a 'single passport' for banks, granting permission to any bank licensed in a member state to operate freely across the European Economic Area. ${ }^{1}$ Banks continued to be supervised by their home country regulator. The Second Banking Directive also required member states to harmonise capital adequacy standards. It did not envisage a role for a region-wide regulatory authority. The Second Banking Directive was fully implemented by the beginning of 1993.

The early 1990s also saw the complete elimination of capital controls across the European Community. The liberalisation of capital flows was necessary as the Single European Act of 1986 required all member countries to remove all legal barriers to an internal market, including barriers to competition and factor mobility in financial services. ${ }^{2}$ In 1988, the European Council adopted a Capital Liberalisation Directive requiring member countries to remove of all remaining exchange controls by mid-1990, with longer transition periods granted for Greece, Ireland, Portugal and Spain. Since 1993, the freedom of capital movements has the same status as the other internal market freedoms. Since 1 January 1994 all restrictions on capital movements and payments between EU member states have been prohibited, as well as restrictions between EU member states and third countries.

As can be seen in Table 1 and Figure 1, besides Germany and the UK, which abolished all capital controls in 1967 and 1979, respectively, all other Western European countries 
maintained a substantial degree of capital controls throughout most of the 1980s. Several countries, including Belgium (1991), France (1990), Greece (1994), Luxembourg (1990), Portugal (1992) and Spain (1992), maintained capital controls until the early 1990s.

[Table 1 and Figure 1 about here]

The Financial Services Action Plan (FSAP) was adopted in May 1999 and included numerous initiatives to ensure the full integration of EU banking and capital markets by 2005. The FSAP had three strategic objectives: (i) establishing a single EU market in wholesale financial services; (ii) making retail markets open and secure; and (iii) development of state-of-the-art prudential rules and supervision. Implementation of the FSAP started in 2001.

The various legislative regulatory harmonisation policies in financial services contributed notably to the deepening of European financial markets and banking integration (KalemliOzcan, Papaioannou, and Peydró, 2010). As shown by Kalemli-Ozcan et al. (2010), 'crossborder banking activities increased significantly among European countries that quickly adopted the financial services Directives of the FSAP' (p. 77).

A further boost to financial integration came from monetary unification. The alleged disappearance of currency risk (which was rediscovered in 2010) for cross-border lending and investment within the European Economic and Monetary Union (EMU) had a 'catalytic effect" and led to 'a continuing process of integration in European financial markets' (ECB, 2012, p. 108). By some estimates, cross-border bilateral bank holdings and transactions rose by about $40 \%$ among euro members countries in the decade after the launch of the euro (Kalemli-Ozcan et al., 2010).

\subsection{Two European crises related to liberalised capital flows}

Since the liberalisation of capital account restrictions, Europe has experienced two major financial crises on a region-wide scale: the EMS crisis in 1992-93 and the euro crisis which has rattled Europe since 2010. Both crises were related to liberalised capital flows in different ways.

\section{The ESM crisis: currency speculation in the face of liberalised cross-border capital flows}

The EMS crisis was a crisis that resulted from speculative attacks on the fixed but adjustable exchange rate pegs that were part of the European Exchange Rate Mechanism (ERM). ${ }^{3}$ The ERM was the centrepiece of the EMS, which was established in 1979 as a European 'miniBretton Woods system' (Cooper, 1999, p. 100). Like the Bretton Woods system in the 1950 and 1960s at the global level, the EMS provided the exchange rate stability that enabled a deepening of trade and investment ties across Western Europe in the 1980s. Throughout the 
existence of the EMS, exchange rate realignments - which were explicitly envisaged as part of the system - were necessary to cope with macroeconomic imbalances which at times created devaluation pressure on EMS member countries with current account deficits. None of these realignments, however, were cause of greater concern or trigger of further financial instability.

This was different when macroeconomic imbalances arose across the EMS countries in the course of Germany's economic post-reunification boom in 1991-92. Germany's Bundesbank, the de facto lead central bank in the EMS (Reade and Volz, 2011), raised interest rates in the face of inflationary pressures in Germany at a time when other EMS countries were in a recession. This coincided with a negative referendum in Denmark on membership in the EMU in June 1992, causing concern that the entire monetary union project may never be realised. Given that membership in the EMS was a precondition for membership in the EMU, speculators thought it less likely that countries would accept high central bank interest rates to stay within the system at a time when unemployment was already high. The imbalances led to massive speculative attacks on several EMS currencies, including the British pound and the Italian lira, both of which were ultimately forced to exit the ERM.

While speculative attacks on fixed exchange rate systems were nothing new at the time (be it in Europe or elsewhere), the EMS crisis was of a new quality as the crisis was not primarily due to fundamental macroeconomic imbalances but rather a concerted, self-fulfilling speculative attack (which subsequently led to the development of so-called second generation models of currency crises). ${ }^{4}$ Indeed, the EMS crisis can be described as the first of a new kind of crisis that would later strike in numerous emerging market economies, including Thailand, Malaysia, Indonesia and Korea in 1997-98.

The major reason why the EMS crisis had this new quality is straightforward: there were no limits to currency transactions. As Wyplosz (2004) puts it:

'In the 10 years between its creation in 1979 and 1990, when capital accounts were freed, there were 12 realignments, most of them involving several currencies. With few exceptions, these realignments came in the wake of speculative attacks, yet the system survived. The first attack that occurred after capital liberalization was lethal' (p. 262).

The EMS crisis demonstrated forcefully what the string of emerging market crises confirmed in the 1990s: maintaining a fixed exchange rate regime akin to the EMS becomes almost impossible in the face of a completely liberalised capital account (Volz, 2006).

Given that the level of financial integration in Europe was still relatively low at the time of the EMS crisis, financial system instabilities were largely contained to the national level. This was very different when the euro crisis broke out in 2010 .

\section{The Euro crisis: a capital flow bonanza ending in tears}

As mentioned above, the introduction of the euro gave further boost to regional financial integration. Indeed, as described by the ECB (2012) the creation of EMU led to 'a surge in intra-euro area crossborder investment' (p. 108, cf. Figure 2). Importantly, by joining the euro, member countries with previously weaker currencies experienced a significant drop in 
nominal and real interest rates, converging to the much lower interest rate level Germany had enjoyed for long (cf. Figure 3). The booms in the periphery countries sparked by the drop in real interest rates gave rise to a European capital flow bonanza. Low interest rates and inflowing capital fuelled unsustainable developments in periphery countries, including excessive credit dynamics and real estate bubbles in Ireland and Spain and excessive fiscal spending in Greece. Moreover, while Germany (which in the first part of the 2000s was commonly referred to as the 'sick man of Europe') experienced a period of slow economic growth and low wages grow, the peripheral boom economies saw compensation grow much faster than productivity (Figure 4 ). ${ }^{5}$ The consequence were real exchange rate appreciations and growing current account deficits in the later crisis countries and real exchange rate depreciation and growing current account surpluses in Germany (Figure 5). The role of capital flows is described by the ECB (2012) as follows:

\footnotetext{
'Increased public and current account deficits were fuelled by freely flowing capital within the Single Market. The strong cross-border capital flows into the non-tradable sector (and into government debt and interbank markets) financed demand rather than supply and imports rather than exports, leading to imbalances that turned out to be unsustainable. As current account deficits widened, countries became increasingly dependent on capital inflows, and a sudden stop of capital inflows could cause financial disruption and severely impact growth. Indeed, when the crisis hit, private capital flows to the euro vulnerable countries reversed and financing constraints became apparent. In some vulnerable countries, private capital flows were largely replaced with ECB and official financing.' (p. 10)
}

[Figures 2, 3, 4 and 5 about here]

The macroeconomic imbalances that built up in the first decade of the euro's existence provided the ground for the euro crisis. Even though the ECB (2015) maintains still today that ' $[\mathrm{u}]$ nder full financial integration, banking markets would efficiently allocate resources to the most productive investment opportunities across the euro area, without frictions in the flow of funds across borders' (p. 27) it is quite clear with hindsight that the allocation of capital was not very efficient in the run-up to the crisis. In many ways the economic crises in Greece, Ireland, Italy, Spain and Portugal resembled the many emerging market crises in which capital flow bonanzas ended with a 'sudden stop' (Calvo, 1998) and a reversal of capital flows (Reinhart and Reinhart, 2009). The capital flow bonanzas in the euro area's periphery countries were made possible because of unrestricted capital flows and tightly integrated banking and capital markets.

The crisis was compounded by severe sovereign-bank interdependences where a worsening of the sovereign's credit position would put the domestic banking system under pressure as the latter has been heavily exposed to the sovereign's debt - which were and still are treated as zero-risk assets by European financial regulators and the Eurosystem. At the same time, the weakening banking sectors would increase the risk that the government would have to bail out the domestic banking system, in turn worsening the credit standing of the sovereign.

The crisis was also worsened by the fact that the financial systems of the Eurozone had become increasingly intertwined and complex. Notwithstanding far-reaching regional 
financial integration, regulation - albeit harmonised - was still the domain of national regulatory and supervisory authorities which failed to cooperate among each other. As acknowledged by the European Commission (2009), '[n]ationally based supervisory models have lagged behind the integrated and interconnected reality of today's European financial markets, in which many financial firms operate across borders. The crisis exposed serious failings in the cooperation, coordination, consistency and trust between national supervisors.'

The crisis demonstrated forcefully that it is not sustainable to foster financial integration but leave regulation and supervision entirely in the hands of national authorities. Schoenmaker and Oosterloo (2008) have referred to this as the 'financial trilemma', a situation where it is impossible to achieve at the same time financial stability, financial integration and maintain national financial policies.

But regulatory failure not only occurred due to a lack of regulation on the regional level. There was also a failure of national and European financial and monetary authorities to look beyond microprudential risk. As can be seen in Table 2, the various regulatory measures that are today commonly referred to as macroprudential regulation (including loan-to-value ratios, debt-to-income ratios, limits on foreign currency loans, reserve requirement ratios) were hardly used in Europe. Irish financial authorities made no attempts to restrain the country's developing asset and property bubbles. Spanish authorities, which also saw the growth of a large property bubble financed by the domestic banking system in the years prior to the crisis, did actually employ loan-to-value ratios but not other loan terms-based instruments that can be used to contain property lending such as loan-to-income ratios, debt-to-income or debtservice-to-income ratios. Also, it did not use capital-based instruments taking into account sectoral and cyclical conditions. In both countries, the burst of property bubbles proved extremely costly - not only for the domestic banks which had financed the property investment but also for the governments which found themselves in a position where they had to bail out the banks, ultimately leaving the bill with the taxpayer.

[Table 2 about here]

\section{Regional financial integration in East Asia - benefits and dangers}

\subsection{Recent trends in regional financial integration in East Asia}

Since the Global Financial Crisis, the East Asian region has seen a trend towards greater regional financial integration (Remolona and Shim, 2015). ${ }^{6}$ While European banks, which had been very active in dollar lending in the years prior to the crisis, have considerably cut down their exposure to the region since the outbreak of the crisis, this gap has been filled by banks from within the region. As a consequence, 'the bulk of the intermediation is now conducted within the region' (Remolona and Shim, 2015, p. 119). ${ }^{7}$

Moreover, there has also been a growing importance of intra-regional portfolio investment. The assets invested in the East Asian region as share of total international investments have 
increased substantially in the region's two leading financial centres (Singapore and Hong Kong) since the early 2000s (Figure 6). Singapore has developed into an important hub for wealth management for regional investors as well as for intermediating flows from outside the region. While a large share $-32.3 \%$ in 2014 - of Hong Kong's total international portfolio investment is directed towards China, it is more modest in the case of Singapore (8.6\% in 2014).

[Figure 6 about here]

The intra-regional portfolio investments of Malaysia and the Philippines have also increased substantially. While Thailand has seen a recent decline in the share of intra-regional investment, this is due to a significant drop of portfolio investment in Korea (from USD 15.1 trillion in 2009 to USD 2.0 trillion in 2014). Leaving out data for Korea, the share of Thai intra-regional portfolio investments has increased since the Global Financial Crisis. In Korea, the share of intra-regional investments has gone down since 2007 due to a decline of investment in China, which has stabilised again only recently.

Despite the recent trends towards greater regional financial integration, the current level of regional financial integration is still low. This is in part related to the fact that many East Asian economies still maintain relatively tight capital controls (Figure 7), but also to the fact that regional capital markets remain rather shallow, with the exception of the major regional financial centres. As mentioned earlier, the historic reliance on financial intermediation in the financial centres of the West hampered the development of capital markets in the East Asian region. This essentially led to a vicious circle of financial underdevelopment and reliance on extra-regional investment and financial intermediation. But it seems that this vicious circle has been broken.

[Figure 7 about here]

The vulnerabilities of emerging East Asian economies that stemmed from an excessive reliance on financial intermediation in the US and Europe and the associated round-tripping of capital (as well as the dangers of premature capital account liberalisation) were painfully illustrated by the Asian Financial Crisis. In the wake of the crisis East Asian countries put in concerted efforts to develop local currency bond markets, which have expanded rapidly since the late $1990 \mathrm{~s} .{ }^{8}$ The crisis also led to efforts at strengthening the regional financial architecture through initiatives such as the Chiang Mai Initiative which was established by the ASEAN Plus Three Finance Ministers Meeting in 2000. The Global - or North-Atlantic Financial Crisis gave further impetus for developing local and regional markets and reducing dependency on Anglo-Saxon financial markets. It also led to the conviction, especially in China, that the region needed to reduce its dependency on the US dollar. 
The general view is that deeper regional financial integration will lessen East Asian economies' reliance on global financial markets for funding and the resulting vulnerabilities to global shocks (e.g., Park and Shin, 2015). Moreover, developing deep and liquid local currency sovereign and corporate bond markets can facilitate much needed long-term investment in infrastructure and other areas needed for sustainable development in the region. Likewise, the development of a solid region-wide banking system that offers important services such as trade and infrastructure finance can contribute to sustainable economic development.

\subsection{ASEAN financial integration}

As recently noted by the Financial Times, financial integration of ASEAN countries is still 'embryonic' (Kynge, 2015). To change this, the ten ASEAN member countries have adopted an ambitious agenda of regional financial integration. Plans to fostering regional financial integration date back to the late 1990s. In 1997, the ASEAN heads of state and government proclaimed the ASEAN Vision 2020 with the goal of building 'a stable, prosperous and highly competitive ASEAN Economic Region in which there is a free flow of goods, services and investments, a freer flow of capital, equitable economic development and reduced poverty and socio-economic disparities' (ASEAN, 1997, emphasis added). The ASEAN Vision 2020 included plans to "promote financial sector liberalisation and closer cooperation in money and capital market, tax, insurance and customs matters as well as closer consultations in macroeconomic and financial policies' (ibid.). In 2003, the ASEAN finance ministers adopted a Roadmap for Monetary and Financial Integration of ASEAN, with concrete measures, timelines and indicators for promoting capital market development, the liberalisation of financial services and capital accounts, and for currency cooperation (ASEAN, 2016). Various working committees have since been set up to flesh out the details of ASEAN's developing financial integration framework. In 2007, the heads of state and government approved the ASEAN Economic Community (AEC) Blueprint for establishing the AEC by 2015. The AEC Blueprint comprises comprehensive provisions regarding financial services sector liberalisation among member states and various measures for advancing capital market development and integration. ${ }^{9}$ In 2011, the ASEAN central bank governors agreed on the ASEAN Financial Integration Framework (AFIF) which was also endorsed by the ASEAN finance ministers. With the AFIF, the ASEAN members aim for 'a semiintegrated financial region by 2020' (ASEAN, 2015a, p. 1). AFIF calls for 'remov[ing] restrictions to the intra-ASEAN provision of financial services by ASEAN financial institutions; build[ing] capacity and infrastructure to develop and integrate the ASEAN capital markets; liberalis[ing] the flow of capital across the ASEAN region; harmonis[ing] payments and settlements systems; [and] strengthen[ing] capacity building, regional financing arrangements, and regional surveillance' (Menon, 2015, pp. 2-3). Figure 8 provides an overview of the different elements of ASEAN financial integration, comprising the ASEAN Banking Integration Framework (ABIF), the ASEAN Insurance Integration Framework, and various initiatives to foster the integration of capital markets. ${ }^{10}$ 
[Figure 8 about here]

While the AEC was formally established at the end of 2015, many of the aims set out in the AEC Blueprint remain unaccomplished. ${ }^{11}$ In November 2015, the ASEAN Economic

Community Blueprint 2025 (ASEAN, 2015c) was published, setting out the agenda for fostering financial integration, financial inclusion and financial stability (Box 1). While pushing for further liberalisation of financial services and capital account restrictions, the AEC Blueprint 2025 adopts a rather cautious tone, emphasising that countries should '[a]llow adequate safeguards measures against potential macroeconomic instability and systemic risks that may arise from the liberalisation process, including the right to adopt the necessary measures to ensure macroeconomic and financial stability' (ASEAN, 2015c, $\S 18.1 . b){ }^{12}$ Given the European experiences discussed above, this caution is warranted.

However, the risks of badly managed capital account liberalisation cannot be overemphasised. Especially for economies with very shallow financial systems, the risks associated with large scale capital inflows are immense. Against this backdrop, the view expressed in a recent study published jointly by the Asian Development Bank (ADB) and the ASEAN Secretariat that '[f]ull and complete capital account and financial services liberalization is ultimately key to the success of the AEC' (ADB, 2013, p. 27) is questionable. Although the same study concedes that 'a gradual and judicious approach is the only pragmatic and feasible option at the present', it advises that 'this must be considered as a step toward the eventual elimination of all restrictions on crossborder capital flows and financial services' (ADB, 2013, p. 27). ${ }^{13}$ Aiming for a complete 'elimination of all restrictions on crossborder capital flows and financial services' for developing and emerging economies may be a recipe for financial crisis.

An important issue that needs to be addressed by policymakers is whether ASEAN countries will be willing to create an ASEAN-wide regulatory structure that matches the comprehensive plans for regional financial integration. The AEC Blueprint 2025 calls for '[i]ntensify[ing] the existing process of macroeconomic and financial surveillance through identifying financial system risks and vulnerabilities, and intensifying exchange of key macroeconomic information among monetary and fiscal authorities' (§ 17.iii.a). It also demands ASEAN member countries to '[f]urther enhance cross-border cooperative arrangements in relation to the implementation of the ABIF' (§ 17.iii.b) and to ' $[\mathrm{m}]$ ake prudential regulations more cohesive [in order to achieve] greater consistency with international best practices and regulatory standards' ( $\$ 17$. iii.c). The question needs to be asked whether this will suffice to ensure financial stability, given the degree of integration that is to be achieved. 


\section{Box 1: AEC Blueprint 2025 provisions on financial integration, financial inclusion and financial stability}

16. Ensuring that the financial sector is inclusive and stable remains a key goal of regional economic integration. The financial sector integration vision for 2025 encompasses three strategic objectives, namely financial integration, financial inclusion, and financial stability, and three crosscutting areas (Capital Account Liberalisation, Payment and Settlement Systems, and Capacity Building).

17. Strategic measures include the following:

i. Strengthen financial integration to facilitate intra-ASEAN trade and investment by increasing the role of ASEAN indigenous banks, having more integrated insurance markets, and having more connected capital markets. These will be supported by robust financial market infrastructure that is safe, cost-efficient, and more connected. Financial liberalisation will be undertaken with greater regulatory cohesiveness to keep requirements for regulatory compliance to a minimum to reduce costs, while remaining prudent.

The key measures are as follows:

a. Further commit to liberalise financial services sector through the ATISA [ASEAN Trade in Services Agreement], which will serve as a platform to link financial markets within the region and with Dialogue Partners;

b. Provide greater market access and operational flexibility for Qualified ASEAN Banks (QABs) through the ASEAN Banking Integration Framework (ABIF), based on each country's readiness and on a reciprocal basis, thereby reducing gaps in market access and operational flexibility across ASEAN;

c. Promote deeper penetration in insurance markets through the ASEAN Insurance Integration Framework (AIIF), with greater risk diversification, deeper underwriting capacity, improved and strengthened insurance sector supervision and regulatory frameworks;

d. Further deepen and interlink capital markets by progressing towards more connectivity in clearing settlement and custody linkages to facilitate investment in the region, and allow investors and issuers to tap cross-border ASEAN capital markets efficiently, in line with the objective of ASEAN Capital Market Infrastructure (ACMI) Blueprint. This will ensure that the benefits of such connectivity are shared by all ASEAN Member States; and

e. Promote the development of sovereign bond markets as well as corporate issuances that will diversify risks from the banking system and provide savers with greater opportunities to invest.

ii. Promote financial inclusion to deliver financial products and services to a wider community that is under-served, including MSMEs [micro, small and medium enterprises]. This would also include initiatives to address the uneven digital gap in the region and reflect changes in the demographic structure, as some countries become aging societies. Key measures are as follows:

a. Enhance the financing ecosystem in the region to benefit MSMEs, including through cross-collaboration among various working groups in ASEAN. Initiatives to be explored may include the establishment of credit bureaus to facilitate the MSMEs in establishing credit standing to improve access to financing, credit guarantee institutions to provide credit enhancement to MSMEs that do not have collateral, other appropriate facilities or mechanisms that will provide financial access for MSMEs, as well as debt resolution agencies to assist distressed but viable MSMEs;

b. Expand the scope of financial access and literacy, as well as intermediary and distribution facilities, such as digital payment services to promote cost-reducing technologies and the development of financial services for smaller firms and lower income groups. Enhance discussion channels in ASEAN to develop best practices and exchange information as well as strengthen cooperation;

c. Intensify the implementation of financial education programmes and consumer protection mechanisms to bolster financial management capacity and encourage take up of financial services. These include raising awareness of personal safeguard measures against deceptive practices as well as enhancing technical countermeasures against threats of digital fraud; and

d. Promote the expansion of distribution channels which improve access to and reduce cost of financial services, including mobile technology and microinsurance.

iii. Ensure financial stability through the continuous strengthening of regional infrastructure, particularly in times of regional stress. Key measures are as follows:

a. Intensify the existing process of macroeconomic and financial surveillance through identifying financial system risks and vulnerabilities, and intensifying exchange of key macroeconomic information among monetary and fiscal authorities. Discussions may complement ongoing efforts by the Financial Stability Board (FSB) at the global level;

b. Further enhance cross-border cooperative arrangements in relation to the implementation of the ABIF with the emergence of regionally active banks during both crisis and in the normal course of business. In the near term, existing regional and bilateral cooperation platforms for macro-surveillance and supervision will continue to perform an integral role. Furthermore, closer dialogues between authorities may be achieved through regional supervisory colleges; and

c. Make prudential regulations more cohesive, aimed at achieving greater consistency with international best practices and regulatory standards.

18. The measures under the three key cross-cutting areas are as follows:

i. Enhance capital account liberalisation to encourage greater flows of capital among ASEAN Member States to facilitate cross-border investment and lending in the region, following these guiding principles:

a. Ensure an orderly capital account liberalisation, consistent with ASEAN Member States' national agenda and the readiness of their economies;

b. Allow adequate safeguards measures against potential macroeconomic instability and systemic risks that may arise from the liberalisation process, including the right to adopt the necessary measures to ensure macroeconomic and financial stability; and

c. Ensure the benefits of liberalisation are shared by all ASEAN Member States. ASEAN will continue to monitor the progress of capital account liberalisation among ASEAN Member States by utilising the ASEAN Capital Account Liberalisation Heatmap and Individual Milestones Blueprint.

ii. Payment and Settlement Systems will be further enhanced in several areas such as promoting standardisation and developing settlement infrastructure for cross-border trade, remittance, retail payment systems and capital markets. This will provide an enabling environment to promote regional linkages and payment systems that are safe, efficient and competitive. This will also require a certain level of harmonisation of standards and market practices based on international best practices (such as ISO 20022) to foster stability and efficiency within as well as outside the region.

iii. Capacity Building will help to narrow the financial development gap in the region. This can be achieved through the conduct of learning programmes and exchanges of knowledge and experiences, and best practices in areas relevant to financial integration and development, such as financial regulation and supervision, financial inclusion, and payment and settlement systems. 
Source: ASEAN (2015c). 
The ABIF is a case in point. Once fully implemented, the ABIF will give so-called Qualified ASEAN Banks (QABs) greater market access in other ASEAN countries. ${ }^{14}$ The AIIB will be therefore somewhat comparable to the single passport for banks in Europe, which has granted permission to any bank licensed in a member state to operate freely across the European Economic Area since the early 1990s. As discussed, it has become evident in Europe that regional banking integration which relied solely on supervision by home country regulators has failed, even though regulation was harmonised. For the time being, ASEAN countries will rely on 'existing regional and bilateral cooperation platforms for macro-surveillance and supervision' while aiming to develop 'closer dialogues between authorities [...] through regional supervisory colleges’ ( $§ 17 . i i i . b)$. Such supervisory colleges may be sufficient as long as QAB status will be extended only to few banks or QABs will be active in only few ASEAN countries. But once ABIF is fully implemented region-wide, regulatory harmonisation and regional supervisory colleges will not suffice to ensure regional financial stability. The European experience suggests that from a certain level of regional financial integration a region-wide regulator is needed. Given this would involve a transfer of sovereignty to the regional level - which ASEAN countries have shown no inclination for whatsoever - this may be politically impossible to achieve. For the time being the level of ASEAN financial integration is still at a fairly low level, but complexity has been rising already. Efforts to enhance the capacity and resources of the ASEAN Integration Monitoring Office to develop surveillance reports, monitoring tools and capacity building programmes (ASEAN, 2015b) are hence appropriate. Moving forward, a more complex and integrated ASEAN banking system would make regional banking supervision obligatory.

To be able to cope with greater cross-border capital flows, the AEC Blueprint 2025 rightly calls for making prudential regulations more cohesive across ASEAN. At the moment, the use of macroprudential measures varies substantially across ASEAN (Table 3). ${ }^{15}$ While risks arising from credit booms and capital inflow volatility can be mitigated by adequate macroprudential measures (Bruno, Shim, and Shin, 2015), regional coordination is important to reduce the risk of cross-border distortions and spillovers arising from unilateral action by member countries. The same holds for capital flow measures; empirical evidence shows that capital flows can be diverted to other economies when one economy imposes capital flow controls (Forbes, Fratzscher, Kostka, and Straub, 2012; Lambert, Ramos-Tallada, and Rebillard, 2011).

[Table 3 about here]

However, it is not only important to have the 'right' frameworks and policies for maintaining financial and macroeconomic stability. Saiki, Chantapacdepong, and Volz (2016) highlight the importance of institutional capacities and good governance for effectively dealing with capital inflow surges. This remains a big challenge especially in the CLMV countries (Cambodia, Lao, Myanmar, Vietnam). In these countries, efforts should be focused on developing human capacity, institutions and infrastructure in the financial system. Peer-topeer learning among ASEAN countries and technical assistance from central banks of 
advanced ASEAN countries can play important roles in capacity building. The ASEAN finance ministers' agreement to continuously strengthen and intensify capacity building efforts (ASEAN, 2015b) should be thus made a priority.

\section{Conclusions}

The literature on (regional) financial integration has long highlighted potential benefits of integration. Meanwhile, recent crisis experiences in Europe and elsewhere have demonstrated the risks to financial and macroeconomic stability arising from regional and international financial integration. Although there are substantial differences between the EU and ASEAN, the European experiences suggest that ASEAN member countries need to be very cautious in implementing their ambitious financial integration agenda. Based on a brief review of two European crisis episodes related to regional financial integration, this article has discussed the risk arising from badly managed integration. The lesser developed ASEAN countries need to be cautious with gradual capital account liberalisation and work on strengthening domestic financial systems and capacities for financial governance. The European experiences clearly show the importance of targeted macroprudential policies in the absence of capital controls. They also underpin the importance of developing an adequate region-wide regulatory and supervisory framework to minimise risks associated with regional financial integration. 


\section{Acknowledgements}

This article is a revised and updated version of a paper prepared for the conference on 'Evolving trade and investment in Asia' at the Lee Kuan Yew School of Public Policy in Singapore, 16-17 September 2015. This article builds on my earlier work in this area (Volz, 2013a, 2013b). Helpful comments by conference participants and especially my discussant Siu Fung Yiu are gratefully acknowledged. 


\section{References}

ADB and ASEAN (2013). The road to ASEAN financial integration: A combined study on assessing the financial landscape and formulating milestones for monetary and financial integration in ASEAN. Manila: Asian Development Bank.

ASEAN (1997). ASEAN vision 2020. Kuala Lumpur, 15 December. Retrieved from http://www.asean.org/news/item/asean-vision-2020

ASEAN (2015a). Summary of achievements of ASEAN financial integration. Document prepared by the ASEAN Senior Level Committee for the $1^{\text {st }}$ ASEAN Finance Ministers' and Central Bank Governors' Meeting. Retrieved from

http://www.kemenkeu.go.id/sites/default/files/SP 2732015.pdf

ASEAN (2015b). Joint statement of the $1^{\text {st }}$ ASEAN Finance Ministers' and Central Bank Governors' Meeting. Kuala Lumpur, March 21. Retrieved from http://www.kemenkeu.go.id/sites/default/files/SP 2732015.pdf

ASEAN (2015c). ASEAN Economic Community Blueprint 2025. Jakarta: ASEAN Secretariat. ASEAN (2016). ASEAN Finance Ministers Meeting (AFMM). Regional cooperation in finance. Retrieved from http://www.asean.org/asean-economic-community/asean-financeministers-meeting-afmm/overview/

Avdjiev, S., McCauley, R. N., \& Shin, H. S. (2015). Breaking free of the triple coincidence in international finance (BIS Working Paper No. 524). Basel: Bank for International

Settlements.

Bruno, V., Shim, I., \& Shin, H. S. (2015). Effectiveness of macroprudential and capital flow measures in Asia and the Pacific. BIS Papers, 82, 185-192.

Buiter, W. H., Corsetti, G., \& Pesenti, P. A. (1998). Financial markets and European monetary cooperation. The lessons of the 1992-93 Exchange Rate Mechanism crisis. Cambridge et al.: Cambridge University Press.

Calvo, G. A. (1998). Capital flows and capital-market crises: The simple economics of sudden stops. Journal of Applied Economics, 1, 35-54.

Cerutti, E., Claessens, S., \& Laeven, L. (in press). The use and effectiveness of macroprudential policies: New evidence. Journal of Financial Stability.

Chantapacdepong, P. (in press). Macroprudential regulation and capital flow management measures in Asia. In: U. Volz \& N. Yoshino (Eds.), Routledge handbook of banking and finance in Asia. London: Routledge.

Chinn, M. D., \& Ito, H. (2006). What matters for financial development? Capital controls, institutions, and interactions. Journal of Development Economics, 81, 163-192.

Cooper, R. N. (1999). Exchange rate choices. In: J. Sneddon Little \& G. P. Olivei (Eds.), Rethinking the international monetary system (pp. 99-123). Boston, MA: Federal Reserve Bank of Boston. 
ECB (2012). Financial integration in Europe. Frankfurt am Main: European Central Bank.

ECB (2015). Financial integration in Europe. Frankfurt am Main: European Central Bank.

Eichengreen, B. J., \& Wyplosz, C. (1993). The unstable EMS. Brookings Papers on Economic Activity, 1, 51-143.

European Commission (2009). European financial supervision. Communication from the Commission COM 2009252 final, Brussels, May 27.

Fernandez, A., Klein, M., Rebucci, A., Schindler, M., \& Uribe, M. (2015). Capital control measures: A new dataset (NBER Working Paper No. 20970). Cambridge, MA: National Bureau of Economic Research.

Forbes, K. J., Fratzscher, M., Kostka, T., \& Straub, R. (2012). Bubble thy neighbor: Portfolio effects and externalities from capital controls (NBER Working Paper 18052). Cambridge, MA: National Bureau of Economic Research.

Genberg, H. (in press). Financial integration in Asia. In U. Volz \& N. Yoshino (Eds.), Routledge handbook of banking and finance in Asia. London: Routledge.

Glick, R., \& Rose, A.K. (1999). Contagion and trade: Why are currency crises regional? Journal of International Money and Finance, 18, 603-617.

Kalemli-Ozcan, S., Papaioannou, E., \& Peydró, J.-L. (2010). What lies beneath the euro's effect on financial integration? Currency risk, legal harmonization, or trade? Journal of International Economics, 81, 75-88.

Kynge, J. (2015, 10 December). Creation of economic community forges new Asean era. Financial Times. Retrieved from http://www.ft.com/intl/cms/s/3/cc929732-9dc5-11e5-b45d4812f209f861.html\#axzz3wxfIkx6C

Lambert, F., Ramos-Tallada, J., \& Rebillard, C. (2011). Capital controls and spillover effects: evidence from Latin-American countries (Working Paper No. 357). Paris: Banque de France.

Menon, R. (2015). ASEAN financial integration - Where are we, where next? Keynote address by Mr Ravi Menon, Managing Director of the Monetary Authority of Singapore, at the ASEAN Banking Council Meeting, Singapore, June 12. Retrieved from http://www.bis.org/review/r150707c.htm.

National Institute of Economic \& Social Research (NIESR) (1997). Capital market liberalization. Prepared for the European Commission's 1996 Single Market Review Series, Subseries III: Dismantling of Barriers, Vol. 5. London: Kogan Page/Earthscan.

Obstfeld, M. (1996). Models of currency crises with self-fulfilling features. European Economic Review, 40, 1037-1047.

Park, C.-Y. (in press). Developing Asian bond markets. In: U. Volz \& N. Yoshino (Eds.), Routledge handbook of banking and finance in Asia. London: Routledge.

Park, D., \& Shin, K. (2015). Financial integration in asset and liability holdings in East Asia (ADB Economics Working Paper No. 444). Manila: Asian Development Bank. 
Passarella, M. (2013). Financial integration in the European Union: An analysis of the $E C B$ 's role (FESSUD Working Paper No. 4). Leeds: Financialisation, Economy, Society and Sustainable Development Project, University of Leeds.

Reade, J. J., \& Volz, U. (2011). Leader of the pack? German monetary dominance in Europe prior to EMU. Economic Modelling, 28, 239-250.

Reinhart, C. M., \& Reinhart, V. R. (2009). Capital flow bonanzas: An encompassing view of the past and present. In: NBER International Seminar on Macroeconomics 2008 (pp. 9-62). Cambridge, MA: National Bureau of Economic Research.

Remolona, E., \& Shim, I. (2015). The rise of regional banking in Asia and the Pacific. BIS Quarterly Review, September, 119-135.

Saiki, A., Chantapacdepong., P., \& Volz, U. (2016). Dealing with QE spillovers in East Asia: The role of institutions and macroprudential policies (ADBI Working Paper). Tokyo: Asian Development Bank Institute.

Schoenmaker, D., \& Oosterloo, S. (2008). Financial supervision in Europe: A proposal for a new architecture. In: L. Jonung, C. Walkner, \& M. Watson (Eds.), Building the Financial Foundations of the Euro. Experiences and Challenges (pp. 337-354). London: Routledge.

Volz, U. (2006). On the feasibility of a regional exchange rate system for East Asia: Lessons of the 1992/1993 EMS crisis. Journal of Asian Economics, 17, 1107-1127.

Volz, U. (2013a). Lessons of the European crisis for regional monetary and financial integration in East Asia. Asia Europe Journal, 11, 355-376.

Volz, U. (2013b). ASEAN financial integration in the light of recent European experiences. Journal of Southeast Asian Economies, 30, 124-141.

Wyplosz, C. (2004). Regional exchange rate arrangements: Lessons from Europe for East Asia. In: Asian Development Bank (Ed.), Monetary and financial integration in East Asia. The way ahead, Vol. 2 (pp. 241-284). Houndmills: Palgrave Macmillan. 
Table 2: Liberalisation of banking activities in EU member states

\begin{tabular}{|c|c|c|c|c|}
\hline & $\begin{array}{c}\text { Lifting of capital } \\
\text { controls }\end{array}$ & $\begin{array}{l}\text { Interest rate } \\
\text { deregulation }\end{array}$ & $\begin{array}{c}\text { First Banking } \\
\text { Directive }\end{array}$ & $\begin{array}{l}\text { Second Banking } \\
\text { Directive }\end{array}$ \\
\hline Belgium & 1991 & 1990 & 1993 & 1994 \\
\hline Denmark & 1982 & 1988 & 1980 & 1991 \\
\hline France & 1990 & 1990 & 1980 & 1992 \\
\hline Germany & 1967 & 1981 & 1978 & 1992 \\
\hline Greece & 1994 & 1993 & 1981 & 1992 \\
\hline Ireland & 1985 & 1993 & 1989 & 1992 \\
\hline Italy & 1983 & 1990 & 1985 & 1992 \\
\hline Luxembourg & 1990 & 1990 & 1981 & 1993 \\
\hline Netherlands & 1980 & 1981 & 1978 & 1992 \\
\hline Portugal & 1992 & 1992 & 1992 & 1992 \\
\hline Spain & 1992 & 1992 & 1987 & 1994 \\
\hline UK & 1979 & 1979 & 1979 & 1993 \\
\hline
\end{tabular}

Source: Buch and Heinrich (2002). 
Table 2: Macroprudential index for European economies

\begin{tabular}{|c|c|c|c|c|c|c|c|c|c|c|c|c|c|c|c|}
\hline & 2000 & 2001 & 2002 & 2003 & 2004 & 2005 & 2006 & 2007 & 2008 & 2009 & 2010 & 2011 & 2012 & 2013 & CB \\
\hline Austria & 0 & 0 & 0 & 0 & 0 & 0 & 0 & 0 & 0 & 0 & 1 & 2 & 2 & 2 & 0 \\
\hline Belgium & 2 & 2 & 2 & 2 & 2 & 2 & 2 & 2 & 2 & 2 & 2 & 2 & 2 & 2 & 0.5 \\
\hline Estonia & 0 & 0 & 0 & 0 & 0 & 0 & 0 & 0 & 0 & 0 & 0 & 0 & 0 & 0 & - \\
\hline Finland & 0 & 0 & 0 & 0 & 0 & 0 & 0 & 0 & 0 & 0 & 0 & 0 & 0 & 1 & 0 \\
\hline France & 2 & 2 & 2 & 2 & 2 & 2 & 2 & 2 & 2 & 2 & 2 & 3 & 3 & 3 & 0 \\
\hline Germany & 0 & 0 & 0 & 0 & 0 & 0 & 0 & 0 & 0 & 0 & 2 & 2 & 2 & 2 & 0.5 \\
\hline Iceland & 1 & 2 & 2 & 2 & 2 & 2 & 2 & 2 & 2 & 2 & 2 & 2 & 2 & 2 & 0 \\
\hline Ireland & 0 & 0 & 0 & 0 & 0 & 0 & 0 & 0 & 0 & 0 & 0 & 0 & 0 & 0 & - \\
\hline Italy & 2 & 2 & 2 & 2 & 2 & 2 & 2 & 2 & 2 & 2 & 2 & 2 & 2 & 2 & 1 \\
\hline Latvia & 0 & 0 & 0 & 0 & 0 & 0 & 0 & 1 & 1 & 1 & 1 & 2 & 2 & 2 & 0 \\
\hline Lithuania & 0 & 0 & 0 & 0 & 0 & 0 & 0 & 0 & 0 & 0 & 0 & 2 & 2 & 2 & 1 \\
\hline Malta & 0 & 0 & 0 & 0 & 0 & 0 & 0 & 0 & 0 & 0 & 0 & 0 & 0 & 0 & - \\
\hline Netherlands & 0 & 0 & 0 & 0 & 0 & 0 & 0 & 0 & 0 & 0 & 0 & 0 & 1 & 3 & 0 \\
\hline Poland & 1 & 1 & 1 & 1 & 1 & 1 & 1 & 1 & 1 & 1 & 2 & 2 & 2 & 2 & 0 \\
\hline Portugal & 0 & 0 & 0 & 0 & 0 & 0 & 0 & 0 & 0 & 1 & 1 & 1 & 2 & 2 & 0.5 \\
\hline Slovakia & 1 & 1 & 1 & 1 & 1 & 1 & 1 & 1 & 1 & 1 & 1 & 2 & 2 & 2 & 0 \\
\hline Slovenia & 0 & 0 & 0 & 0 & 0 & 0 & 0 & 0 & 0 & 0 & 0 & 0 & 0 & 0 & - \\
\hline Spain & 3 & 3 & 3 & 3 & 3 & 3 & 3 & 3 & 3 & 3 & 3 & 3 & 3 & 3 & 0.3 \\
\hline Sweden & 0 & 0 & 0 & 0 & 0 & 0 & 0 & 0 & 0 & 0 & 1 & 1 & 1 & 1 & 0 \\
\hline United Kingdom & 0 & 0 & 0 & 0 & 0 & 0 & 0 & 0 & 0 & 0 & 0 & 0 & 0 & 0 & - \\
\hline
\end{tabular}

Source: Compiled with dataset from Cerutti, Claessens, and Laeven (in press).

Note: The macroprudential index ranges from 0 to 12. The higher the index, the more of the following macroprudential tools are employed: Loan-to-Value Ratio Caps, Debt-to-Income Ratio, Time-Varying/Dynamic Loan-Loss Provisioning, General Countercyclical Capital Buffer/Requirement, Leverage Ratio, Capital Surcharges on Systemically Important Financial Institutions, Limits on Interbank Exposures, Concentration Limits, Limits on Foreign Currency Loans, FX and/or Countercyclical Reserve Requirements, Limits on Domestic Currency Loans, Levy/Tax on Financial Institutions. CB stands for fraction of macroprudential instruments that are controlled by the central bank as of 2013 and ranges from 0 to 1 . 
Table 3: Macroprudential index for East Asian economies

\begin{tabular}{|c|c|c|c|c|c|c|c|c|c|c|c|c|c|c|c|}
\hline & 2000 & 2001 & 2002 & 2003 & 2004 & 2005 & 2006 & 2007 & 2008 & 2009 & 2010 & 2011 & 2012 & 2013 & $\mathrm{CB}$ \\
\hline Brunei & 0 & 0 & 0 & 0 & 0 & 1 & 1 & 1 & 1 & 1 & 1 & 1 & 3 & 3 & 1 \\
\hline Cambodia & 2 & 2 & 2 & 2 & 2 & 2 & 2 & 2 & 2 & 2 & 2 & 2 & 2 & 2 & 1 \\
\hline China & 1 & 1 & 1 & 2 & 4 & 4 & 4 & 4 & 5 & 5 & 5 & 7 & 7 & 8 & 0.3 \\
\hline Hong Kong & 3 & 3 & 3 & 3 & 3 & 3 & 3 & 3 & 3 & 3 & 3 & 3 & 3 & 3 & 1 \\
\hline Indonesia & 0 & 0 & 0 & 0 & 0 & 1 & 1 & 1 & 1 & 1 & 1 & 1 & 2 & 2 & 0.5 \\
\hline Japan & 1 & 1 & 1 & 1 & 1 & 1 & 1 & 1 & 1 & 1 & 1 & 1 & 1 & 1 & 0 \\
\hline Lao PDR & 2 & 2 & 2 & 2 & 2 & 2 & 2 & 2 & 2 & 2 & 2 & 2 & 2 & 2 & 1 \\
\hline Malaysia & 2 & 2 & 2 & 2 & 2 & 2 & 2 & 2 & 2 & 2 & 2 & 2 & 2 & 2 & 1 \\
\hline Philippines & 1 & 1 & 2 & 2 & 2 & 2 & 2 & 2 & 2 & 2 & 2 & 2 & 2 & 2 & 0.5 \\
\hline Singapore & 1 & 1 & 2 & 2 & 2 & 2 & 2 & 2 & 2 & 2 & 2 & 2 & 2 & 5 & 0.8 \\
\hline South Korea & 0 & 0 & 1 & 1 & 1 & 2 & 2 & 3 & 3 & 3 & 3 & 4 & 4 & 4 & 0.5 \\
\hline Thailand & 0 & 0 & 0 & 1 & 1 & 1 & 1 & 1 & 1 & 1 & 1 & 2 & 2 & 2 & 1 \\
\hline Timor-Leste & 1 & 1 & 1 & 1 & 1 & 1 & 1 & 1 & 1 & 1 & 1 & 1 & 1 & 1 & 1 \\
\hline
\end{tabular}

Source: Compiled with dataset from Cerutti et al. (in press).

Note: The macroprudential index ranges from 0 to 12 . The higher the index, the more of the following macroprudential tools are employed: Loan-to-Value Ratio Caps, Debt-to-Income Ratio, Time-Varying/Dynamic Loan-Loss Provisioning, General Countercyclical Capital Buffer/Requirement, Leverage Ratio, Capital Surcharges on Systemically Important Financial Institutions, Limits on Interbank Exposures, Concentration Limits, Limits on Foreign Currency Loans, FX and/or Countercyclical Reserve Requirements, Limits on Domestic Currency Loans, Levy/Tax on Financial Institutions. CB stands for fraction of macroprudential instruments that are controlled by the central bank as of 2013 and ranges from 0 to 1. 
Figure 1: Capital account openness in European countries, 1970-2013

Austria

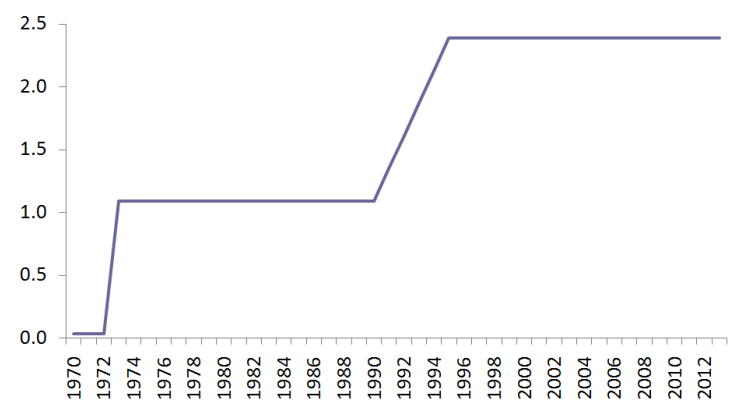

Denmark

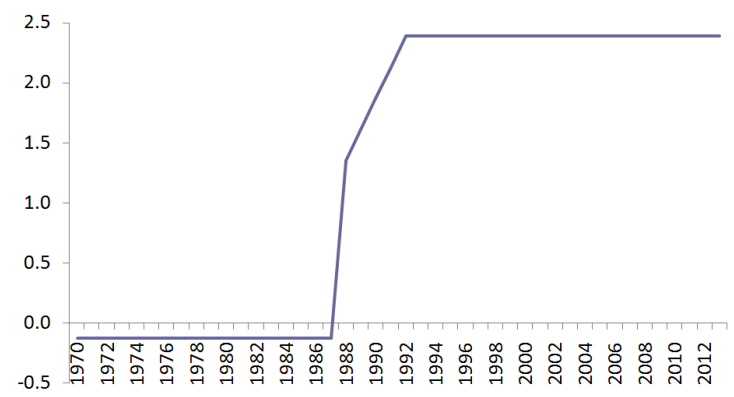

France

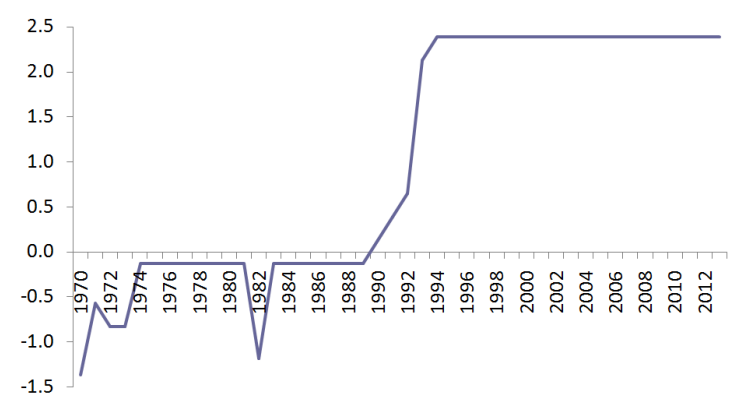

Greece

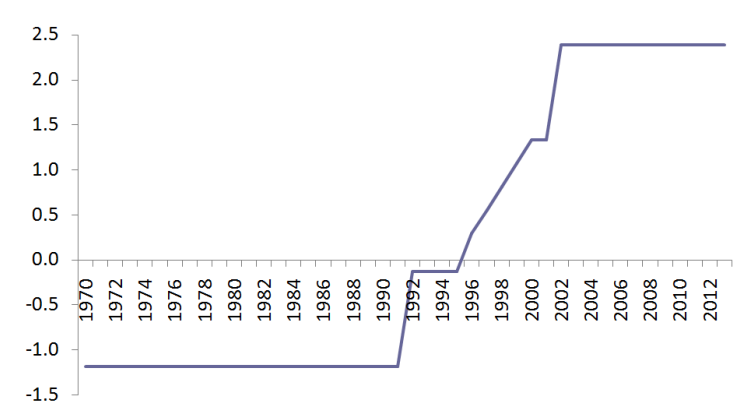

Belgium

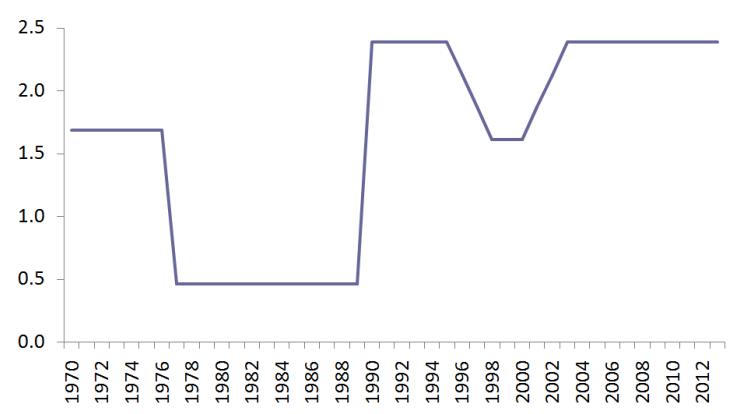

Finland

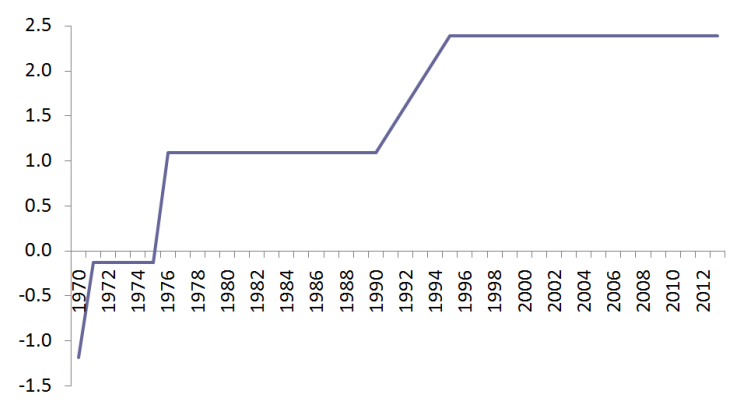

Germany
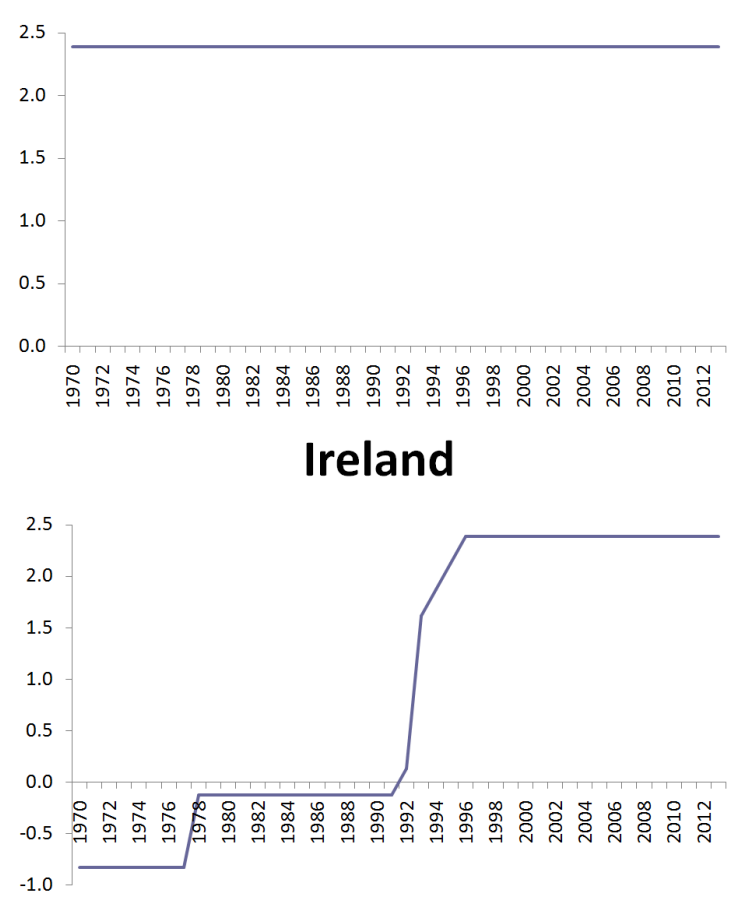
Italy

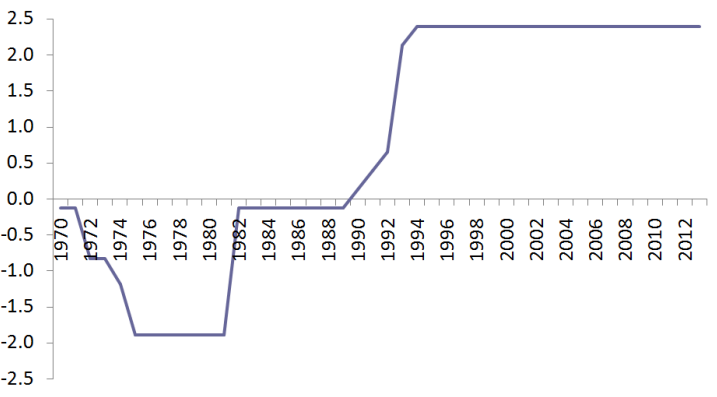

Netherlands

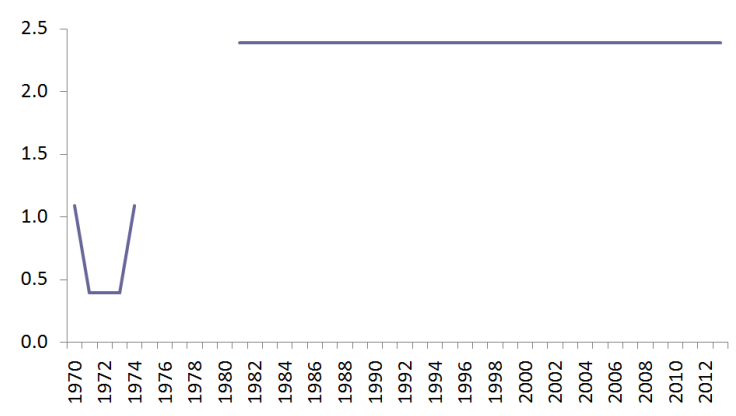

Portugal

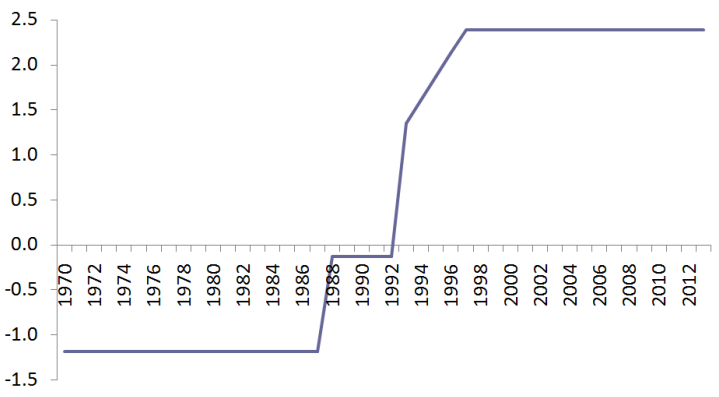

Sweden

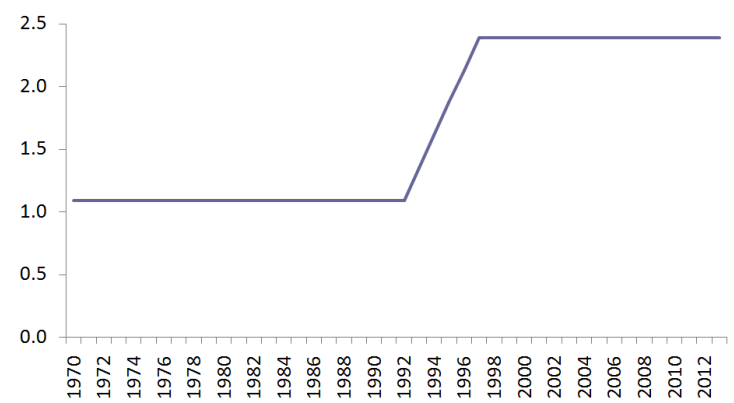

Malta

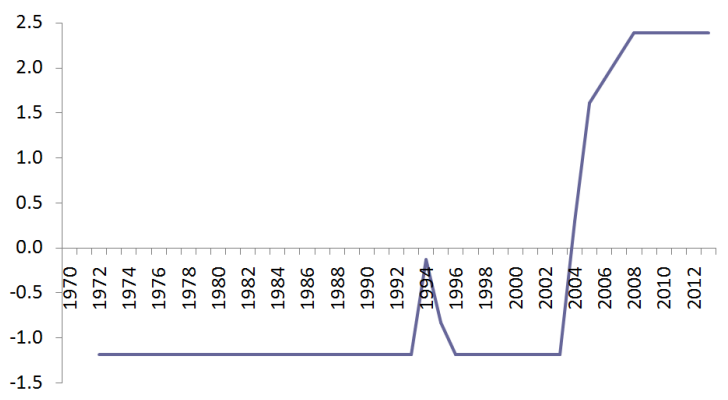

Norway

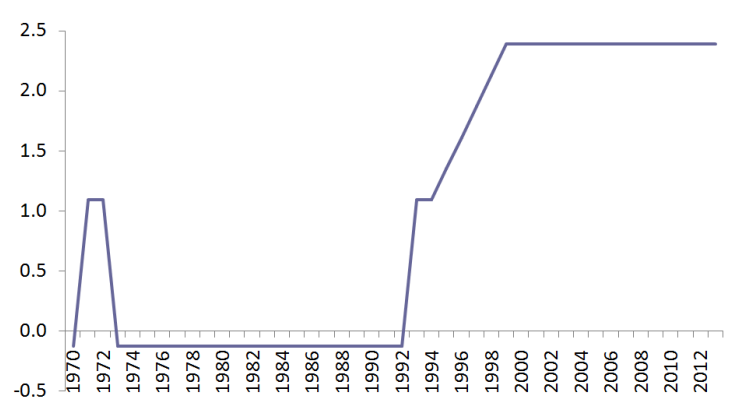

Spain

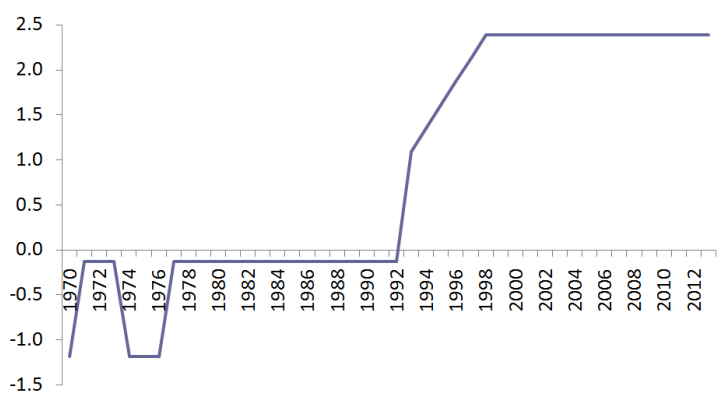

United Kingdom

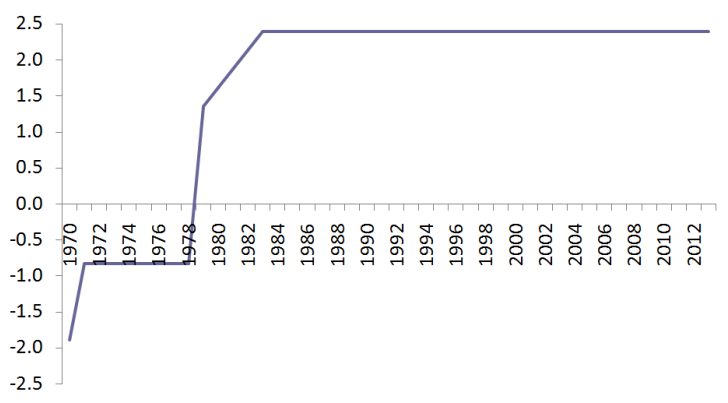

Source: Compiled with the KAOPEN dataset from Chinn and Ito (2006).

Note: A higher value of the Chinn-Ito Index indicates a more open capital account. A value of -2.5 indicates a completely closed capital account, while a value of 2.5 indicates a completely liberalised capital account. 
Figure 2: Price-based and quantity-based financial integration composites (FINTECs)

- price-based FINTEC

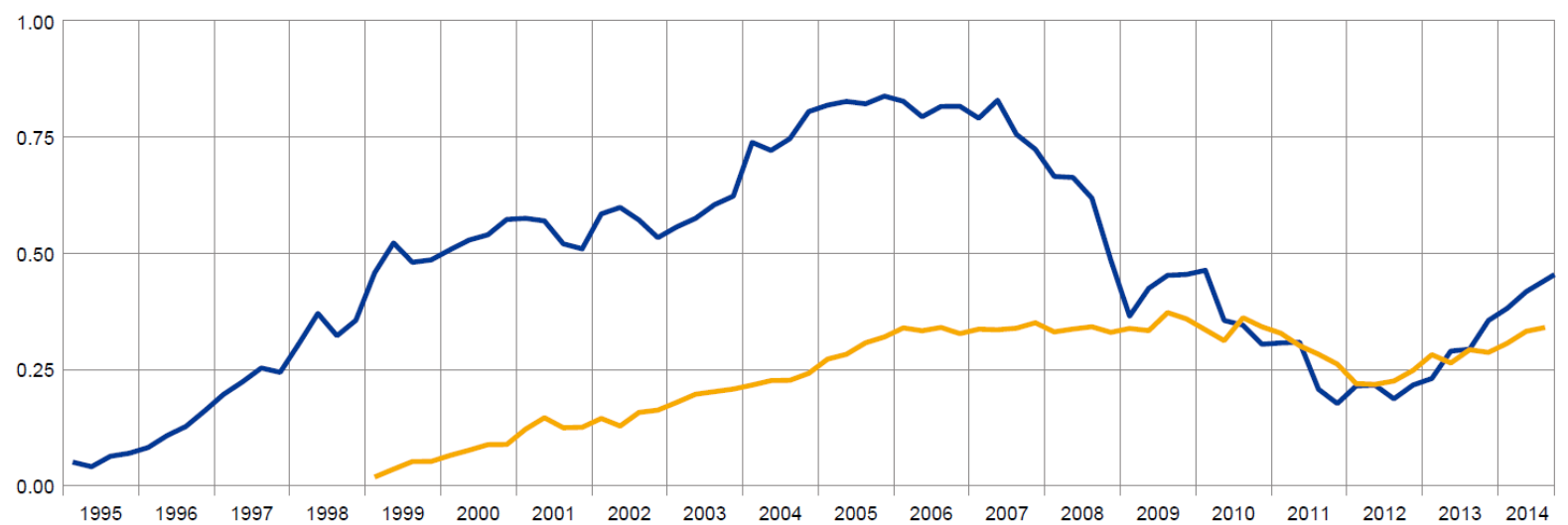

Source: ECB, Financial Integration in Europe, April 2015

Notes: The price-based FINTEC aggregates ten indicators covering the period from the first quarter of 1995 to the fourth quarter of 2014, and the quantity-based FINTEC aggregates five indicators available from the first quarter of 1999 to the third quarter of 2014. The FINTEC is bounded between zero (full fragmentation) and one (full integration). Increases in the FINTEC signal higher financial integration. 
Figure 3: 10-year government bond yields (\% p.a.), 1990:Q1 - 2015:Q2

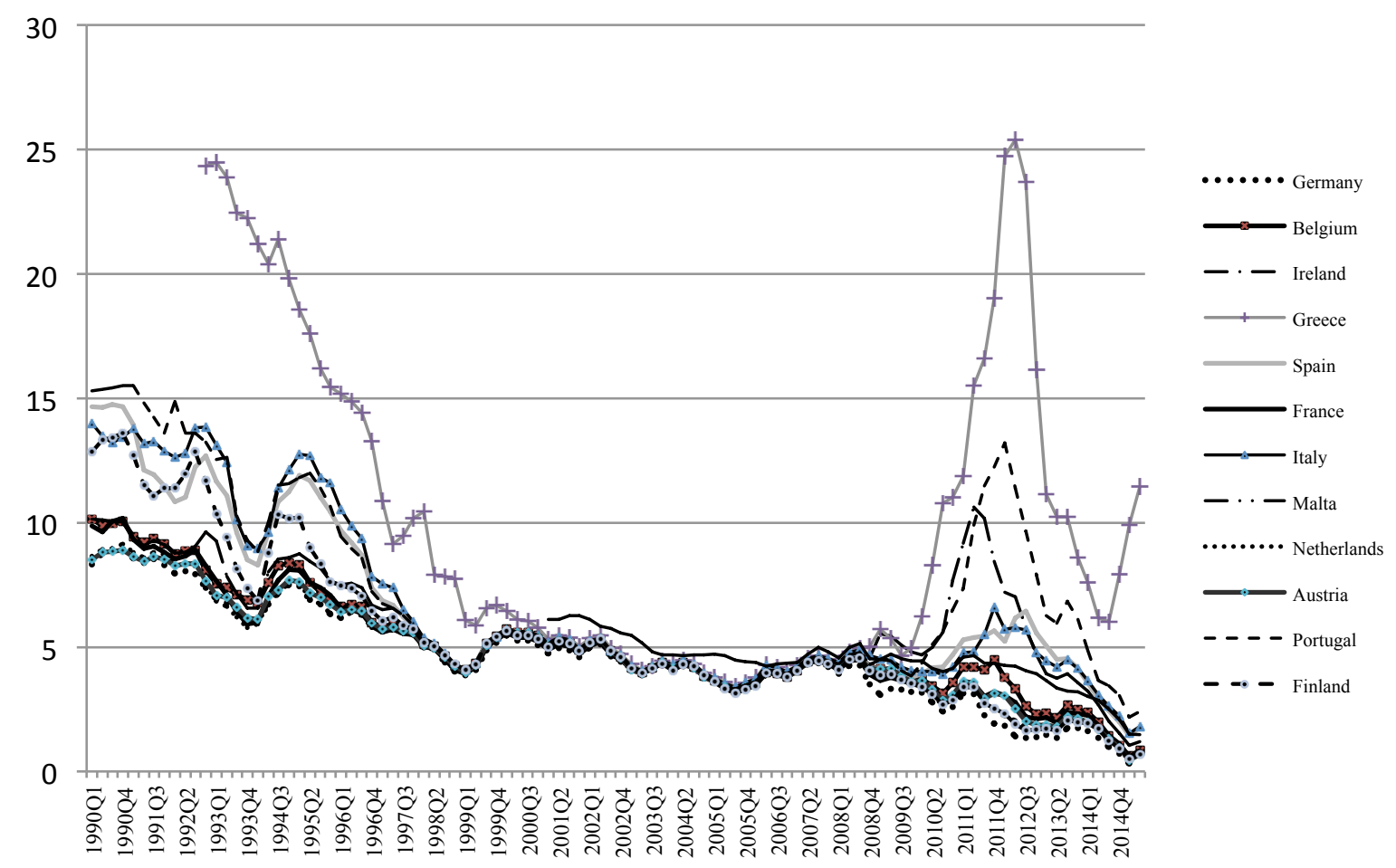

Source: Compiled with data from Eurostat. 
Figure 4: Compensation and total factor productivity developments (dotted line) in selected euro area countries $(1998=100), 1998-2015$
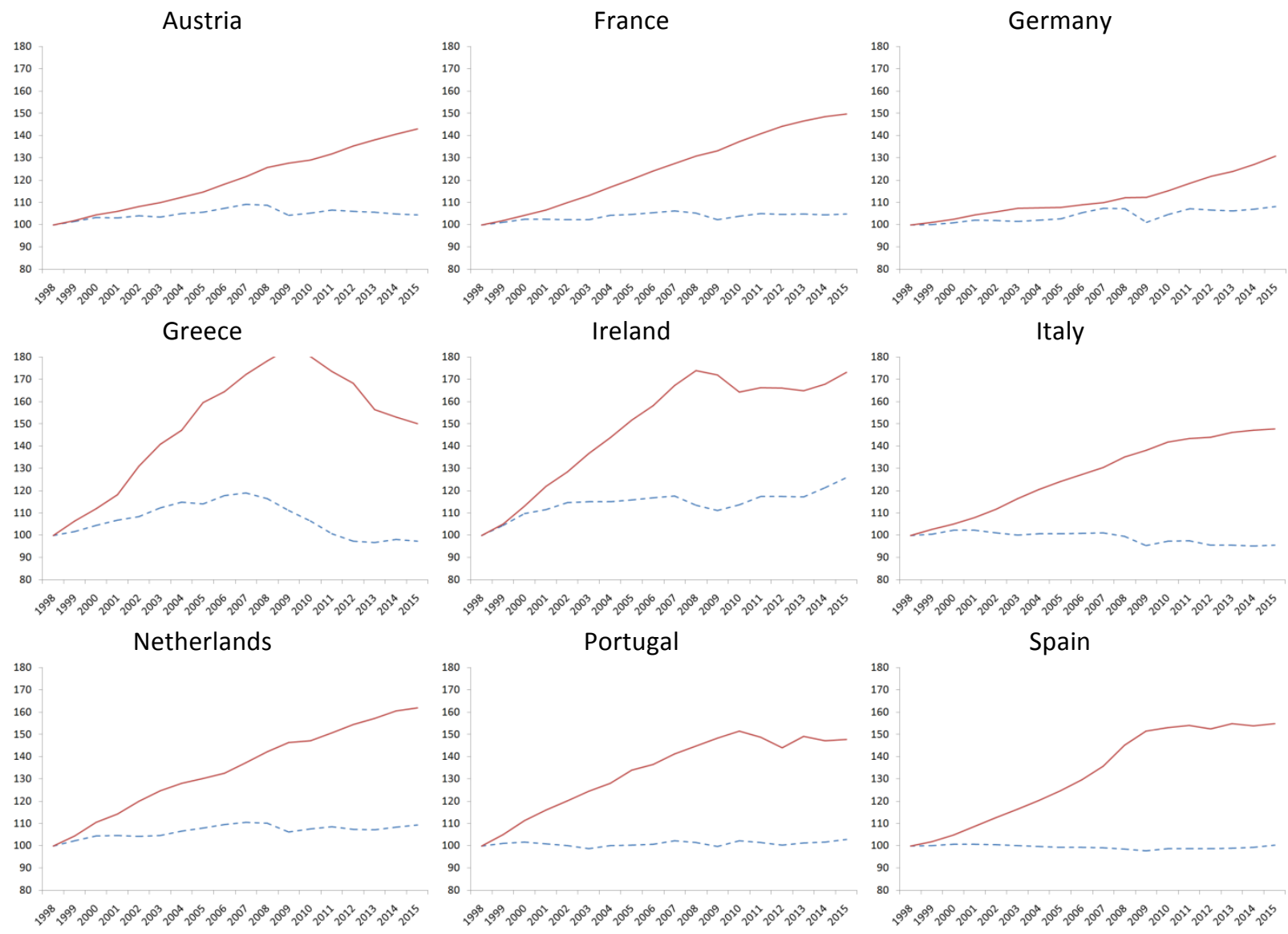

Source: Compiled with data from the European Commission's Annual Macro-economic Database. 
Figure 5: Cumulated current account balance of Eurozone countries (in bn EUR), 19982015

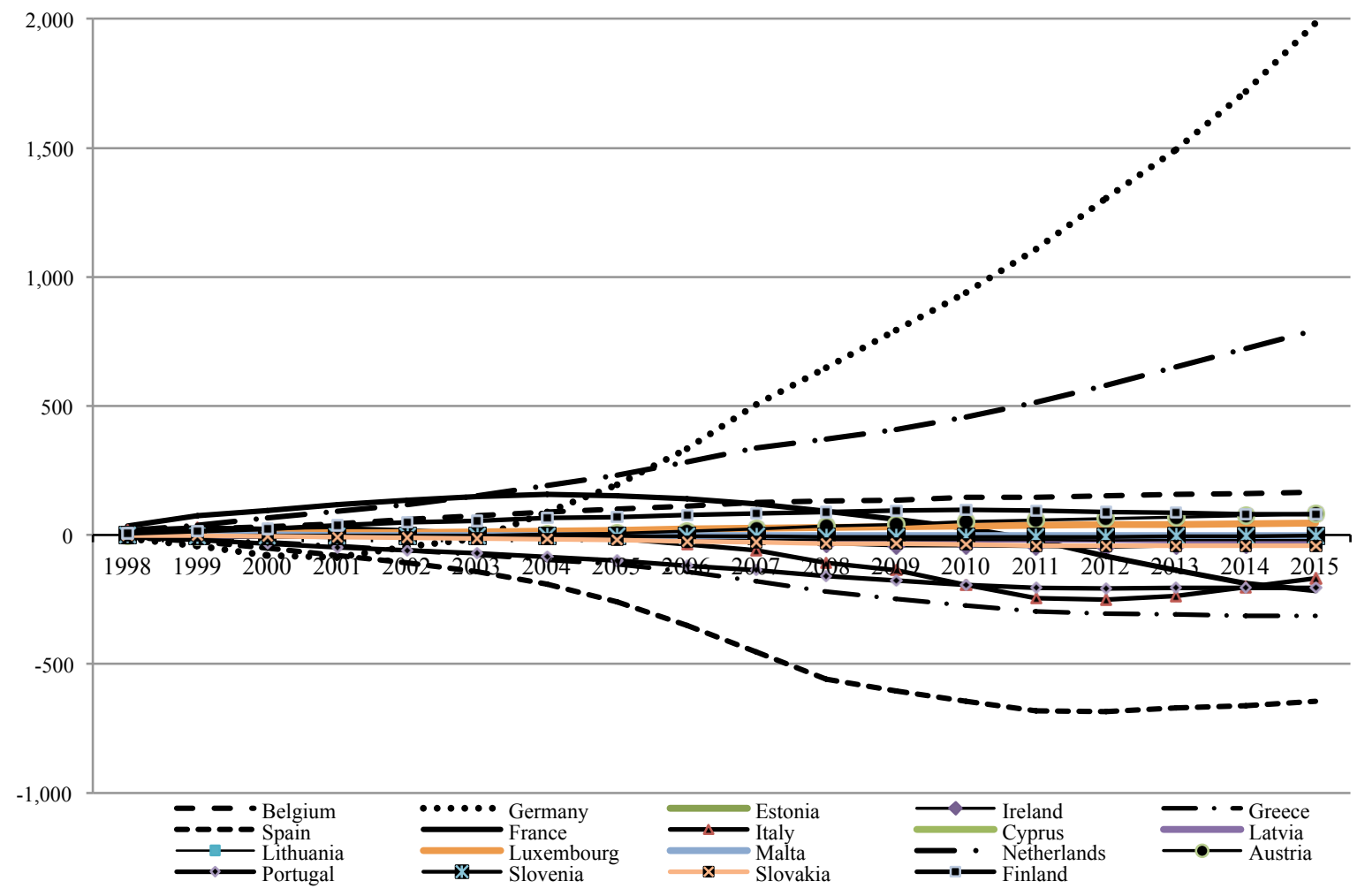

Source: Compiled with data from the European Commission's Annual Macro-economic Database. 
Figure 6: Assets invested in the East Asian region as share of total international asset investments (in \%)

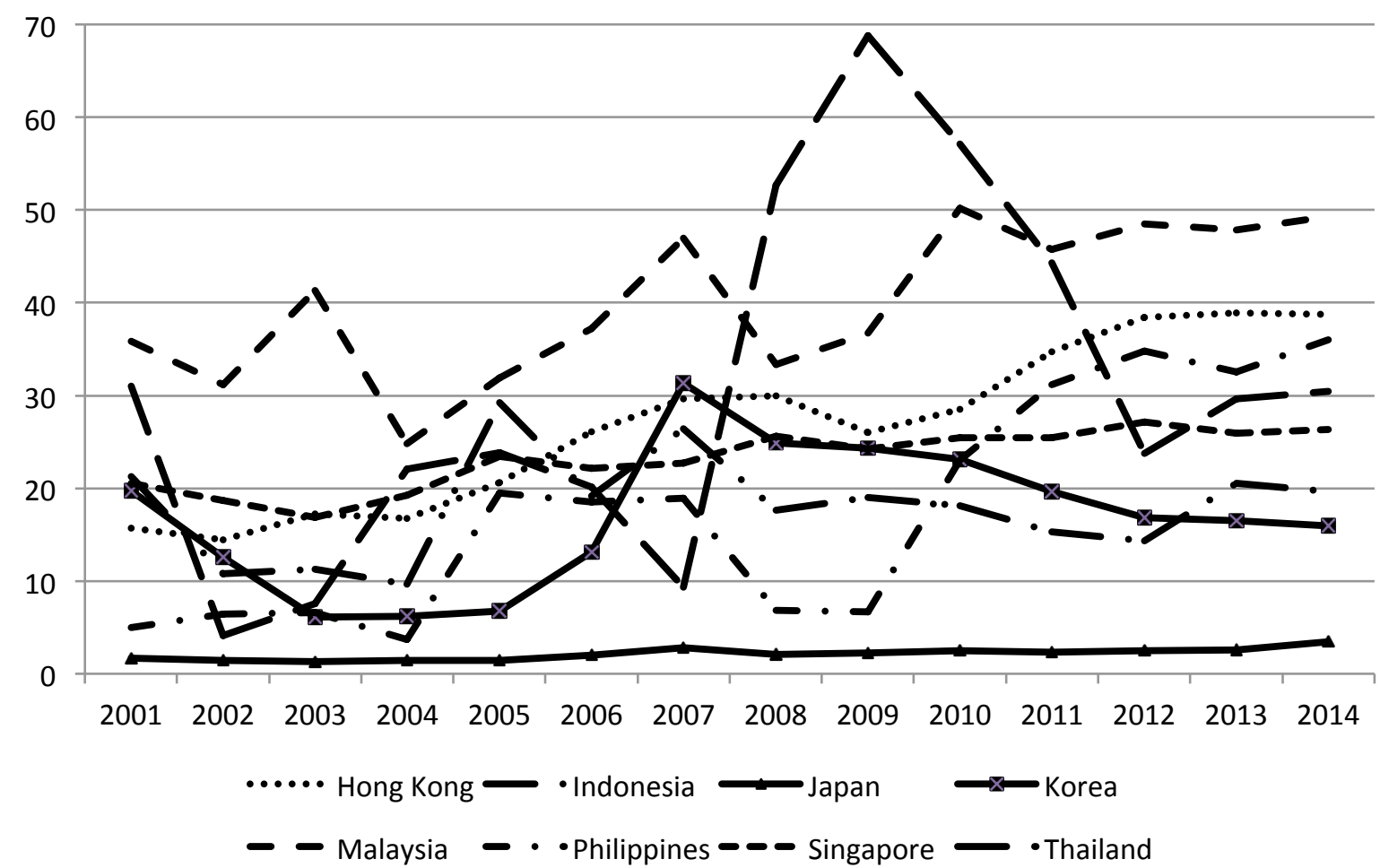

Source: Compiled with data from the IMF's Coordinated Portfolio Investment Survey (CPIS).

Note: Data are for investment in ASEAN, China, Japan, Korea, Hong Kong, Macao and Taiwan. *Data for investment in Japan is missing for Singapore. 
Figure 7: Capital inflow and outflow restrictions of East Asian countries in 2013

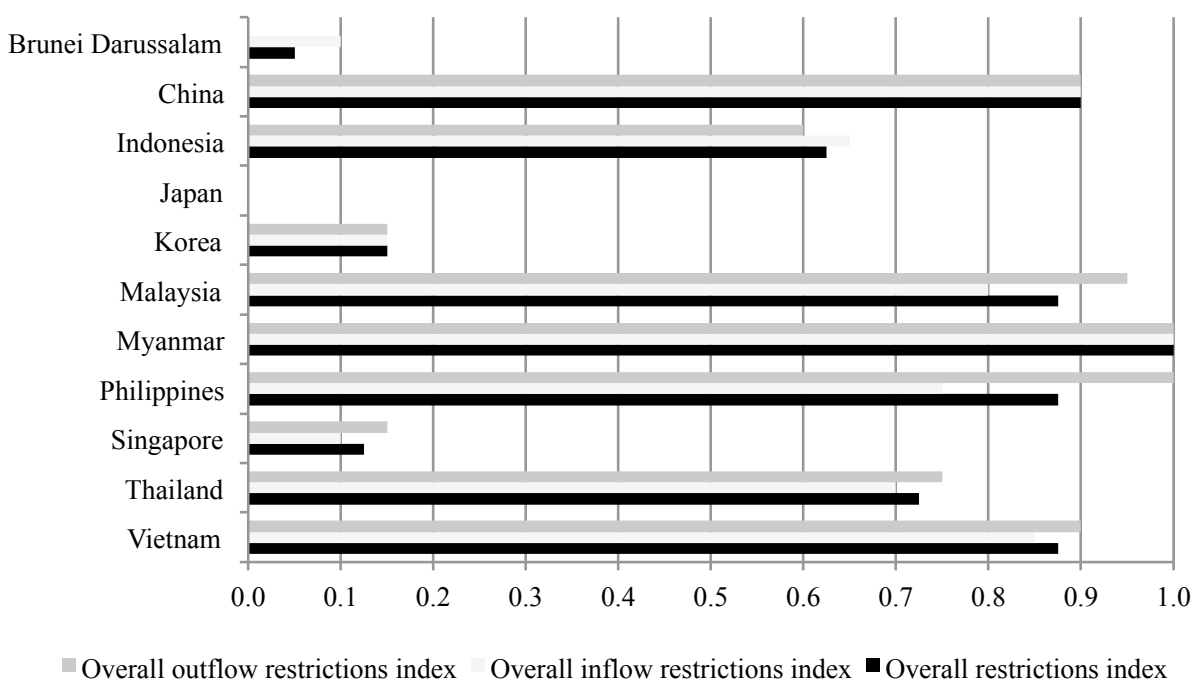

Source: Compiled with dataset from Fernandez, Klein, Rebucci, Schindler, and Uribe (2015).

Note: A higher value indicates more restrictions. A value of 0 indicates a completely liberalised capital account. 
Figure 8: ASEAN financial integration

\begin{tabular}{|c|c|c|}
\hline \multicolumn{3}{|c|}{ ASEAN Framework Agreement on Services (AFAS) } \\
\hline $\begin{array}{c}\text { Banking } \\
\text { ASEAN Banking Integration } \\
\text { Framework }\end{array}$ & $\begin{array}{c}\text { Insurance } \\
\text { ASEAN Insurance Integration } \\
\text { Framework }\end{array}$ & $\begin{array}{c}\text { Capital markets } \\
\text { ASEAN Trading Link } \\
\text { ASEAN Disclosure Standards } \\
\text { ASEAN Corporate Governance } \\
\text { Scorecard } \\
\text { Bond market development }\end{array}$ \\
\hline \multicolumn{3}{|c|}{ Payment and settlement systems } \\
\hline \multicolumn{3}{|c|}{ Capital account liberalisation } \\
\hline
\end{tabular}

Source: Adapted from ASEAN (2015a, p. 2). 


\footnotetext{
${ }^{1}$ The European Economic Area consists of the member countries of the European Union (previously European Community) as well as Iceland, Liechtenstein and Norway.

${ }^{2}$ On capital market liberalisation see, for instance, NIESR (1997).

${ }^{3}$ See, for instance, Buiter, Corsetti, and Pesenti (1998), Eichengreen and Wyplosz (1993) and Volz (2006).

${ }^{4}$ The first second generation crisis model was developed by Obstfeld (1996).

${ }^{5}$ The slow growth in Germany was partly related to entering the euro at an overvalued exchange rate.

${ }^{6}$ For a recent survey of financial integration in Asia see Genberg (in press).

${ }^{7}$ See also Avdjiev, McCauley, and Shin (2015).

${ }^{8}$ Initiatives to foster bond market development include the ASEAN+3 Asian Bond Market Initiative and the Asian Bond Fund initiatives of the Executives' Meeting of East Asia Pacific Central Banks (EMEAP). See Park (in press).

${ }^{9}$ For a discussion of these provisions, see Volz (2013b).

${ }^{10}$ These include, among others, the ASEAN Trading Link, which electronically connects exchanges in Malaysia, Singapore and Thailand; the ASEAN Disclosure Standards (which have been signed up to by Malaysia, Thailand and Singapore) to facilitate multi-jurisdictional offering of equity and debt; the ASEAN Corporate Governance Scorecard aiming to raise corporate governance standards and practices; and the ASEAN Bond Market Development Scorecard which monitors the development of bond markets. Cf. ASEAN (2015a).

${ }^{11}$ ASEAN (2015a) provides an overview of the "achievements" of ASEAN financial integration. See also Menon (2015).

${ }^{12}$ This provision is also included in the original AEC Blueprint.

${ }^{13}$ The study, which was launched on the sidelines of the $9^{\text {th }}$ ASEAN Central Bank Governors meeting in Brunei in April 2013, was endorsed by the ASEAN Central Bank Governors (2013) "as an important reference for ASEAN to further guide its financial integration process."

${ }^{14}$ The ABIF was endorsed by the ASEAN Central Bank Governors in December 2014. For the moment, QAB status will be granted through reciprocal bilateral agreements between two ASEAN central banks. These agreements will specify details of home-host regulatory and supervisory cooperation to ensure effective surveillance and supervision of QABs. Banks that have achieved QAB status will be allowed to operate in both countries involved (not in the entire ASEAN area) and will be granted the same operational flexibilities of domestic banks in the respective host country.

${ }^{15}$ For an overview of macroprudential regulation and capital flow management measures in Asia see Chantapacdepong (in press).
} 